\title{
Personalet trenger diab
}

\author{
Foreldre til og barn med diabetes blir tryggere av at de som er sammen \\ med barnet i hverdagen lærer om sykdommen.
}

D iabetes er den vanligste kroniske sykdommen blant barn og ungdom i Norge. Sykdommen rammer rundt 300 barn hvert år (1). Forekomsten av diabetes hos barn er økende, og Norden ligger på verdenstoppen. Man antar at årsaken er en kombinasjon av arvelig disposisjon, genetiske forhold og ukjente miljøfaktorer (2). Diabetes er en tilstand som krever en jevnlig oppfølging av blodsukkeret gjennom dagen. Dette gjelder spesielt barn i skole- og barnehagealder. Å ivareta et barn med diabetes på skole eller i barnehage krever god kunnskap om sykdommen (3).

\section{Lovfestet}

Lov om opplæring i grunnskolen slår fast at skolen skal drive kontinuerlig og systematisk arbeid for å fremme elevers helse, miljø og trygghet (4). Forskrift om miljørettet helsevern i barnehager og skole sier at man skal tilrettelegge tilbudet for det enkelte barn basert på opplysninger om barnets helsetilstand. For at barn med diabetes skal få oppfylt disse forskrifts- og lovmessige rettighetene må man å ta spesielle hensyn. Forholdene må legges til rette slik at

\section{Hovedbudskap}

Vi ønsker å gi helsesøstere et hjelpemiddel i deres jobbhverdag. For å bidra til at det legges et tilfredsstillende grunnlag for opplæring av skole- og barnehagepersonell for å håndtere barn med diabetes. På denne måten vil man trygge foreldre og barn i hverdagen deres, som igjen vil fremme trivsel, vekst og utvikling hos barnet.

\section{Søkeord}

Les mer og finn litteraturhenvisninger på våre nettsider. > Diabetes > Barn । Kronisk sykdom \Helsesøster alle som har ansvar for barn med diabetes får informasjon og nødvendig kunnskap om sykdommen (5).

\section{Undervisning}

Tilbakemeldinger vi har fått fra helsesøstrene viser at det kan gå mange år mellom hver gang de skal holde denne type undervisning, og at de ønsker ett undervisningsverktøy de kan benytte, slik at undervisningen de gir er oppdatert og riktig. Barneavdelingen i Vestre viken har samarbeid mellom første- og andrelinjetjenesten som et uttalt mål og satsingsområde. Som spesialisthelsetjeneste dekker vi et stort geografisk område. Vi møtte stadige utfordringer med å tilby lik tjeneste i lokalmiljøet til alle barn og unge med nyoppdaget diabetes med tanke på opplæring av ansatte i skole og barnehage samt deres medelever. Vi så et behov for å styrke kompetansen til førstelinjetjenesten i ivaretakelse av barn og ungdom med nyoppdaget diabetes.

\section{Litteratursøk}

Vi har gjennomført litteratursøk i databasene Cinahl, Pubmed og Swemed for bakgrunnsinformasjon, med søkeordene: Children, Education, Adolesents, School, Nurse, Diabetes type 1. Her fant vi internasjonale studier som påpekte betydningen av at ansatte som skal ivareta barnet i skole eller barnehage får god opplæring. Undervisningsverktøyene i Danmark fant vi ved å besøke det danske diabetesforbundet sine nettsider. Studier fra USA og England viser en signifikant bedre diabeteskontroll hos skolebarn som blir ivaretatt av voksne som har fått opplæring i håndtering av diabetes (6). Der hvor medelever har fått den samme undervisningen, opplever barnet bedre livskvalitet enn der de ikke hadde fått det (6). En svensk undersøkelse viser at ved sju års alder stiger HbA1c (langtidsblodsukker), samtidig rapporterer samme undersøkelse at det er 20 prosent av foreldrene som gir mindre insulin til barna sine grunnet redsel for hypoglykemi i løpet av skoledagen (7). Barnediabetesregisteret viser 0,5-1 prosent stigning av HbAlc fra sju til ni års alder. En årsak til dette kan være frykt for hypoglykemi og skolepersonalets håndtering av dette (8). I en studie fra Haukeland sykehus uttaler foreldrene at de frykter hypoglykemi fordi de er usikre på hvordan deres barn blir ivaretatt på skolen (9). Gjennom forsknings- og erfaringsbasert kunnskap om hva familier med kronisk syke har behov for ser vi verdien av å øke helsesøstres kunnskap. Slik kan de videreformidle kunnskap til ansatte i skole og barnehage $(6,10)$.

\section{Mangler kunnskap}

Helsesøstre har mye kompetanse om barn og utvikling, men ikke alltid oppdatert kunnskap om alle sykdomstilstander. Dette bekrefter også en studie fra USA hvor helsesøstres tilbakemeldinger viser at de ikke hadde tilstrekkelig kunnskap om diabetes til å håndtere denne i skolehverdagen (11). Utfordringen ligger i hvilken type kompetanse som kreves for å gi adekvat undervisning til de som skal ivareta barnet, og videre hvordan kompetansen skal opprettholdes og videreutvikles.

I Norge finnes det lite materiell som kan brukes i diabetesundervisning av barn og ansatte ved skole og i barnehage. Gjennom våre søk i litteraturen har vi ikke funnet noe standardisert undervisningsverktøy som helsesøstre kan benytte seg av i undervisning av ansatte, barn og unge. Det finnes nettbaserte PowerPointpresentasjoner som er utarbeidet i samarbeid med Diabetesforbundet. Men disse er ikke utarbeidet spesielt for å nå barn og ungdom og er etter vår mening derfor lite egnet for undervisning av denne aldersgruppen. Det samme gjelder undervisning av ansatte i skole og barnehage; det er viktig at disse mottar konkrete 


\section{etesopplæring}

råd og veiledning om hvordan de skal mestre sin jobbhverdag.

\section{Skole og barnehage}

Skole og barnehage er den arenaen hvor barn og unge tilbringer mest tid utenfor hjemmet. Vi har derfor utviklet et standardisert undervisningsprogram rettet mot ansatte i skole og barnehage, samt medelever, fordi vi ønsker å kvalitetssikre den opplæringen som blir gitt. Vår bakgrunn for å utarbeide dette verktøyet er at barn, ungdom og deres familier skal føle seg trygge og ivaretatt

i hverdagen

$(6,10)$.

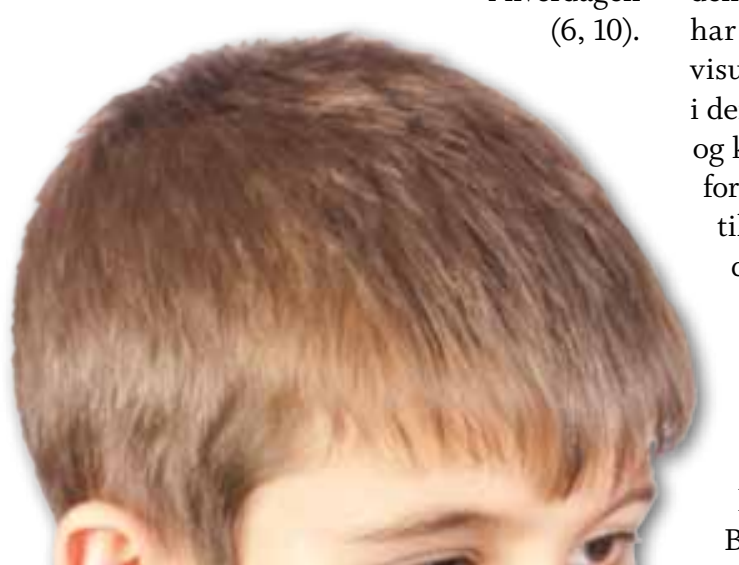

TRYGG: Det er viktig at lærere og medelever vet hvordan de skal hjelpe barn og unge med diabetes. Illustrasjonsfoto: Colourbox.
Vi har utarbeidet tre typer undervisningsverktøy ettersom barn og voksne har forskjellig motivasjon for å lære: Ett for ansatte i barnehage og skole, ett for elever fra seks til tolv år og ett for elever 13-16 år.

\section{Tilpasset målgruppen}

I undervisningsverktøyet som er utarbeidet for barn og unge har vi benyttet oss av utviklingspsykologi, slik at de får informasjon tilpasset sitt utviklingstrinn og sin alder. Det er kognitive fellestrekk for aldersgruppene. I for eksempel den yngste aldersgruppen, fra seks til tolv år, har vi vektlagt at undervisningen skal være visuelt utformet og konkret formulert. Barn i denne aldersgruppen har behov for tydelige og konkrete forklaringer, og det er vanskelig for dem å se saker fra flere synsvinkler. Evnen til logisk og abstrakt tankegang er størst når det tas utgangspunkt i kjente gjenstander og situasjoner. (12). Ved å ta hensyn til disse særtrekkene er man med på å sikre at barn i denne aldersgruppen lettere forstår undervisningen. Men det er store variasjoner innad i aldersgruppen, og det må man ta høyde for når man holder undervisningen. Barn og voksne har forskjellig motivasjon for å lære. Undervisningsverktøyet for ansatte baserer seg på prinsipper for voksenopplæring. Voksne er motivert for å lære det de trenger for å mestre sin jobbhverdag. I denne gitte situasjonen trenger de kunnskap om hvordan de skal håndtere ulike situasjoner, for eksempel med føling (13). Videre har vi valgt å ta med sykdomslære for å kunne gi en bedre og helhetlig forståelse av sykdommen (14). Det er også utarbeidet et støttehefte med mer utfyllende informasjon om sykdomslære. Dette heftet er utarbeidet som et supplement til helsesøstere som ønsker mer utfyllende kunnskap og kan benyttes til forberedelse av undervisningen.

\section{Brukermedvirkning}

Brukermedvirkning har vært en viktig del av dette prosjektet. Vi startet med en kartlegging av hva helsesøstre anså som viktige temaer i undervisningsverktøyet. Dette ble gjort ved å sende ut en e-post til alle helsestasjoner i Buskerud. De ble spurt om egen kompetanse og hva slags hjelpemidler de trenger for å ivareta barn med diabetes på en god måte. Underveis hadde vi jevnlig dialog med lærere og førskolelærere for å undersøke om vår informasjon treffer dem som målgruppe. Helsesøstrene svarte at 
de trengte tilstrekkelig informasjon for å være barn og unges støttespillere i skole- barnehagehverdagen. Men det var vanskelig for dem å uttale seg om hva slags informasjon de ønsket som yrkesgruppe. Vi har fått 30 helsesøstre i Drammensregionen samt Diabetesforbundet og Ung Diabetes, til å komme med innspill i prosessen.

\section{Innhold}

Vi ønsker å bidra til en standardisert og kvalitetssikret undervisning. Målet for undervisningen er å øke kunnskapen til elever og ansatte i skole og barnehage. God kompetanse hos personalet vil gi trygghet i personalgruppa, noe som vil medføre at barnet og dets pårørende føler seg bedre ivaretatt i skole og barnehage. Innholdet i undervisningen er viktig, og man må velge ut temaer som er hensiktsmessige for målgruppen. Det er viktig å begrense undervisningen til det ansatte og elever faktisk trenger i sin hverdag. Nytteverdien av lærestoffet må synliggjøres, og

\section{«God kompetanse hos personalet vil gi trygghet i personalgruppa.»}

det må skapes relevans til skole- og barnehagehverdagen. Tilbakemeldingene vi har fătt av helsesøstre er at de har teoretisk kunnskap, men mangler praktisk erfaring. Den teoretiske undervisningen er derfor støttet opp med praktiske råd og veiledning som er aktuelle i en skole- og barnehagehverdag. Dette er temaer som skal hjelpe barn og unge til å mestre hverdagen på skolen og i barnehagen på en hensiktsmessig måte. Det viktigste er hvordan man skal behandle føling, da dette er en akutt tilstand som krever strakstiltak fra dem som er i nærheten av barnet. Ved å

\section{Tabell 1: Sentrale temaer i undervisningsverktøyet}

\begin{tabular}{|l|l|}
\hline Tema & Elementer \\
\hline Hva er diabetes & $\begin{array}{l}\text { - forskjell på type l og type 2 } \\
\text {-autoimmunsykdom } \\
\text { - årsaker }\end{array}$ \\
Insulin & - virkningsmekanisme \\
Blodsukker & $\begin{array}{l}\text { - normale blodsukkerverdier } \\
\text { - praktisk mpåling } \\
\text { - hva påvirker blodsukkeret }\end{array}$ \\
Føling & $\begin{array}{l}\text { - symptomer } \\
\text { - tiltak }\end{array}$ \\
\hline
\end{tabular}

motta undervisning om disse temaene vil ansatte og medelever øke sin kompetanse og trygghet på området, men også foreldrene og barnet eller ungdommen med diabetes vil føle seg tryggere. Ansatte må føle seg trygge på sin kunnskap om diabetes for å kunne behandle disse barna og ungdommene på lik linje med øvrige barn og unge i skole og barnehage.

\section{Implementering}

Undervisningsverktøyet ble presentert på møtet til Barnediabetesregisteret i mai 2011. Verktøyet er på god vei til å bli implementert lokalt og er presentert nasjonalt, men det er ikke gjort noe videre for en nasjonal implementering. Det ble gjennomført en fagdag for helsesøstre i Buskerud, Asker og Bærum kommune i januar 2011. Her fikk de instruksjoner om hvordan undervisningsverktøyet kan brukes, samt svar på spørsmål om verktøyets bruk og tilgjengelighet.

Når et barn får diagnosen diabetes blir de aktuelle helsesøstrene kontaktet for å gi undervisning på den skolen eller barnehagen der barnet går. Dette er i tråd med Vestre Vikens behandlingslinje for nyoppdaget diabetes hos barn. Helsesøstrene får tilsendt undervisningsverktøyet gratis på e-post. De får videre veiledning i bruk av verktøyet per telefon fra en av diabetessykepleierne på Barnepoliklinikken.

\section{Veiledning}

Hvis helsesøstere opplever faglig usikkerhet, bistår vi med personlig veiledning ved Barnepoliklinikken. Personalet på poliklinikken står for undervisningen sammen med helsesøstere i skole og barnehage. På den måten vil helsesøstere være bedre rustet til å holde undervisningen selv ved en annen anledning. Man vil alltid møte utfordringer når noe nytt skal implementeres. $\mathrm{Vi}$ vet at helsesøstrene har mange oppgaver allerede, og ikke alltid har mulighet til å fordype seg i diagnoser og problemstillinger de møter i hverdagen. Dette har vi tatt utgangspunkt i når vi arrangerer fagdag for helsesøstrene. Vi understreker at dette er et ressursbesparende hjelpemiddel som vil kreve mindre forberedelser i forkant av undervisningen. Det er Barneavdelingen ved Vestre Viken HF som har det faglige ansvaret for oppdatering av undervisningsverktøyet.

\section{Oppsummering}

Tilbakemeldingene fra ansatte og pårørende er at budskapet som blir gitt er klart og tydelig. De ansatte synes de har fått gode råd og retningslinjer som er til hjelp i jobbhverdagen. Både ansatte og pårørende sier de opplever større trygghet etter at undervisningen er gitt. Man har sendt ut e-post til de helsesøstrene som har benyttet undervisningsverktøyet, med spørsmål om brukervennlighet, og om de synes målgruppen ble nådd. Tilbakemeldingene har så langt vært positive. Helsesøstrene har blant annet uttalt: «kunnskapsrikt og praktisk!» og «flotte illustrative bilder, med kort og konsis tekst».

Når man lager et standardisert verktøy er det viktig å ta hensyn til individuelle forskjeller hos barn, unge og deres familier. Man må ta med både foreldre og barnet eller ungdommen når man forbereder undervisningen slik man ivaretar individuelle behov. Verktøyet trenger kontinuerlig evaluering og oppdatering, både med tanke på utviklingen innen det medisinske fagområdet, men også når det gjelder brukervennlighet for helsesøstrene. Prosjektet er utviklet for og av praksis. Undervisningsverktøyet har ikke vært systematisk evaluert. Slik sett kan prosjektet betraktes som en pilot som kan testes både av barna selv, foreldre, lærere og helsepersonell.

Tilbakemeldingene vi har fătt viser at dette er et verktøy som er tatt godt imot både av dem som bruker verktøyet i undervisning, men også av dem som har fått undervisningen. Verktøyet kan bidra til at barn og unge med diabetes får en tryggere hverdag i skole og barnehage, ved at både ansatte og medelever har kompetanse om deres sykdom og hvilke tiltak som kreves. IIII

\section{LITTERATUR:}

Joner G. Type I diabetes: nasjonalt og internasjonalt. I: Vaaler S. Diabeteshåndboken. Oslo: Gyldendal Norsk Forlag, 2004. Side 14

. Skafjeld A. Diabetes - Grunnboken for sykepleiere og annet helsepersonell. Oslo: Akribe Forlag, 2002

3. Hanås R. Bli ekspert på din egen diabetes - type l diabetes hos barn, ungdom og unge voksne. 3. utg. Oslo: Cappelen Damm AS., 2011

4. LOV 1998-07-17 nr. 6l: Lov om grunnskolen og den vidaregåande opplæringa. http://www.lovdata.no/cgi-wift/ldles? xdoc=/all/nl-19980717-061.html\#9-4 http://www.lovda

5. Forskrift om miljørettet helsevern i barnehager og skole m.v., Helse- og omsorgsdepartementet, 1995. http://www.lovdata.no/for/sf/ho/xo-19951201-

sorgsdepartementet, 1995. http://Ww 6. Wagner J, Heapy A, James A, Abbott G. Brief report: Glycemic control, quality of
life, and school experiences among students wtih diabetes. Journal of Pediatric Psychology 2006; 31(8): 764-769.

7. Särnblad S, Berg L, Detlofsson I, Forsander G, Jönsson Å. Diabetes i skolan 2008 - en nationell enkätstudie. Stockholm. 2010 (http://diabetes.se/Templates/ Extension__ 4355.aspx) (16.11.11 kl.11.08)

8. Skrivarhaug T. Nasjonalt medisinsk kvalitetsregister for barne- og ungdomsdiabetes. Arrsrapport 2009.http://www.oslo-universitetssykehus.no/SiteCollectionDocuments/Om\%20oss/Avdelinger/Kvinne-\%20og\%20barneklinikken/ Barnediabetes/Ârsrapport2009.pdf (16.11.11 kl. 09.46)

9. Haugstvedt A, Wentzel-Larsen T, Graue M, Søvik O, Rokne B. Fear of hypoglycemia in mothers and fathers of children with type 1 diabetes is associated with mia in mons and fathers of children with type ldiabeses is associated with study. Diabetic Medicine 2010; 27:72-78. 1. Amillategui B, Calle JR, Alvarez MA, Cardiel MA, Bario R. Identifying the special need of children with type 1 diabetes in the school setting. And overview of need of children with type l diabetes in the school setting. An

parents perceptions. Diabetes Medicine 2007; 24:1073-1079.
I1. Joshi A, Komlodi A, Arora M. School nurses) perceived barriers to diabetes knowledge, communication and management in children with type I diabetes. School Nurse News 2008 May; 25(3): 24-9.

12. Bunkholdt V. Utviklingspsykologi. Oslo: Universitetsforlaget, 2003.

13. Tveiten S. Pedagogikk i sykepleiepraksis. 2. utg. Oslo: Fagbokforlaget, 2008. 4. Jacobsen D, Kjeldsen SE, Ingvaldsen B, Buanes T, Røise O. Sykdomsłære, Indremedisin, kirurgi og anestesi. I. utgave. Oslo: Gyldendal Norsk Forlag, 2009 